\title{
Knowledge and Attitude of Lactating Mothers and Health Professionals
}

\author{
Towards Pasteurized Donor Human Milk Banking: A Preliminary \\ Study on the Feasibility of Establishing Donor Human Milk Banking in
} Neonatal Intensive Care Unit of Selected Hospitals in Addis Ababa

\author{
Alemu M, Gashu D and Abera A* \\ Center for Food Science and Nutrition, College of Natural Science, Addis Ababa University, \\ Ethiopia
}

*Corresponding author: Adane Abera, Center for Food Science and Nutrition, College of Natural Science, Addis Ababa University, Ethiopia, Email: adaneet@hotmail.com

\section{Research Article}

Volume 6 Issue 2

Received Date: March 09, 2021

Published Date: April 15, 2021

DOI: $10.23880 /$ fsnt-16000266

\section{Abstract}

Background: Breast milk provides the optimal nutrition for growing infants. This is because it contains all the nutrients a baby needs in exactly the right proportions. It also contains biologically active live cells which promote health and helps to develop a passive acquired immunity by transferring antibodies developed by the mother. But, there are a large group of infants such as; pre-term, low birth weight and ill infants who are unable to breastfeed. On such condition, WHO recommends pasteurized donor human milk as the next best feeding option? However, its use is limited to industrialized countries and few developing countries. Thus, this study was designed to generate preliminary information on the knowledge and acceptability of pasteurized donor human milk banking.

Methods: An institutional based descriptive cross sectional study was conducted to analyze the knowledge and attitude of mothers and health professional towards pasteurized donor human milk banking. In addition, the microbial safety of raw and pasteurized breast milk stored at -20 0C for 60 days was studied. Moreover, the flavor change of raw and pasteurized breast milk over 60 days of storage time was assessed.

Result: Small number of mothers (5\%) ever heard about donor human milk banking. About $53.7 \%$ of health professionals did not know donor human milk banking. All health professionals use infant formula as alternative to breast milk when mother unable to breastfeed. Only $20 \%$ of study mothers could accept feeding their baby donor human milk by physician prescription. Safety or fear of transfer of disease (85.1\%) was the main factor for mothers not interested to feed their baby donor human milk. On the contrary, about two-third of study mothers were willing to donate their breast milk if human milk banking will be established. Three-fourth of health professionals believed that it is feasible to establish pasteurized donor human milk banking. Lack of knowledge about its safety by mothers and health professionals is the major challenge in establishing pasteurized donor human milk banking. In pasteurized breast milk sample stored at -20 0C (deep freezer) for 60 days no bacterial growth was detected. However, in raw breast milk samples a mean of $4.66 \log 10 \mathrm{CFU} / \mathrm{ml}$ of total aerobic plate count, $3.22 \log 10 \mathrm{CFU} / \mathrm{ml}$ of Enterobacteriaceae, $3.49 \log 10 \mathrm{CFU} / \mathrm{ml}$ of Staphylococcus aureus were detected. Within 60 days of storage time, pasteurized milk samples did not devolve off flavor. However raw breast milk samples developed off flavor.

Conclusion: the present study showed that majority (95\%) of mothers never heard about pasteurized donor human milk banking and substantial number (80\%) of mothers did not went to feed their baby even after short description due to fear to transfer of disease. Additionally, more than half of health professionals never heard about pasteurized donor human milk banking. Similarly, fear of disease transfer and safety during processing of pasteurized donor human milk banking is the major 
concern mentioned by most health professionals on its acceptability. In our microbiological analysis Within 60 days of storage time pasteurized donor human milk was bacteriological safe and has acceptable sensory quality.

Keywords: Donor Human Milk; Low Birth Weight; Premature Birth

Abbreviations: ABM: Academy of Breast Feeding Medicine; AIDS: Acquired Immune Deficiency Syndrome; BFHI: Baby Friendly Hospital Initiatives; CDC: Center for Disease Control; CMV: Cytomegalo Virus; DHM: Donor Human Milk; DHMB: Donor Human Milk Banking; FDA: Food and Drug Administration; FMOH: Federal Ministry of Health; HIV: Human Immune Deficiency Virus; HMBANA: Human Milk Banking Association of North America; ICMBMS: International Code of Marketing Breast Milk Substitute; IGA: Immunoglobulin A, IGM: Immunoglobulin M; MBFI: Mother Baby Friendly Initiative; MD: Millennium Development; PDHM: Pasteurized Donor Human Milk; PDHMB: Pasteurized Donor Human Milk Banking; UNICEF: United Nation Children Fund; WHO: World Health Organization

\section{Introduction}

Breast milk provides the optimal nutrition for growing infants. This is because it contains all the nutrients a baby needs in exactly the right proportions, which are easily digestible and well tolerable by infant's immature gut. It also contains immunological and protective substances which promote health and helps to develop a passive acquired immunity by transferring antibodies developed by the mother [1]. In recognition of the vital role that breast milk plays in boosting infant's growth, development and overall health; the World Health Organization (WHO) recommends exclusive breastfeeding for the first six months of a child's life $[2,3]$.

To make this recommendation more practical and ensure that more families around the world have the support they need for breastfeeding and infant health; WHO and the United Nations Children's Fund (UNICEF) established the Baby-Friendly Hospital Initiative (BFHI) and, more recently, the Mother-Baby Friendly Initiative (MBFI). These initiatives encourage health facilities to provide a supportive, familycentered environment for breastfeeding and continuity of care before, during, and after birth $[4,5]$.

But there are a large group of infants such as; pre-term, low birth weight and ill infants who are unable to breastfeed. Moreover, significant number of mothers face difficulties during lactation to provide sufficient amount of milk for their babies or totally unable to provide breast milk especially for the first 72 hours after delivery. To complicate the situation, some mothers may be prevented from breastfeed if they have lesion on their breast, untreated tuberculosis, under chemotherapy treatment and other risky health condition. Furthermore, premature infants are weak and their muscles are not well coordinated to suck and swallow the breast milk. In addition, preterm and low birth weight infants at the time of birth mostly are admitted or incubated in Neonatal Intensive Care Unit (NICU) of the hospital, so the environment is not suitable to breastfeed [6].

However, it is crucial that, those who are born preterm or with low birth weight, have access to human breast milk for proper growth, nutrition, and the prevention of infections or other complications that may lead to longer-term care, cost, or premature death [7-9].

On such condition, WHO recommends Pasteurized Donor Human Milk (PDHM) as the next best feeding option? Also in its sixty-first health assembly; WHO urges member state to provide support for research on the safe use of expressed and donated breast milk, owing to the current challenges facing countries in the implementation of safe infant feeding practices $[10,11]$.

In Ethiopia the coverage of exclusive breastfeeding rate is about $52 \%$, which is still sub optimal and is far from widely accepted-universal coverage $\|$ target of $90 \%$ set by WHO [12]. On the other hand neonatal mortality rate in the country is high equivalent to 37 deaths per 1000 live birth [13,14]. Inadequate exclusive breastfeeding has a great share on neonatal morbidity and mortality. Having all babiesssactcoe exclusive breastfeeding alone reduces the neonatal mortality and morbidity, specially the death that occur soon after birth (early neonatal death) by $13 \%$ [13].

Pasteurized Donor Human Milk Bank (PDHMB) is an organization that screen breast milk donating mothers, collect, process, and store and dispense to needy infants based on the physician prescription. The purpose of PDHMB is protecting, promoting and supporting exclusive breastfeeding by filling the gap when new born baby is unable to breastfeed to own mother.

However; despite the importance of pasteurized donor human milk for vulnerable infants, its use is limited to industrialized countries and in a very few developing countries such as South Africa. So establishing this life saving 


\section{Food Science \& Nutrition Technology}

service has of paramount importance. As the idea of PDHMB is new to Ethiopia, the challenges such as knowledge and attitude of mothers and health professionals, microbiological safety and sensory quality of expressed and stored breast milk is not clearly known. Therefore this study was designed to provide information on the challenges and opportunities towards the use of pasteurized donor human milk in health facilities in Addis Ababa.

\section{Objectives}

\section{General Objective}

To assess the knowledge and attitude of mothers, and health professionals towards pasteurized donor human milk banking and the challenges of its establishment in health settings.

\section{Specific Objectives}

1. To assess knowledge and attitude of lactating mothers, nurses, midwifery, and physicians regarding pasteurized donor human milk banking

2. To learn the prospectus and challenges in establishing pasteurized donor human milk banking

3. To examine the microbial safety and sensory quality of pasteurized donor human milk over storage time and temperature

\section{Literature Review}

\section{Exclusive Breastfeeding Practices}

Exclusive breastfeeding has been defined by WHO as the situation where the infant has received only breast milk from own mother or a wet nurse, or expressed breast milk and no other liquids, or solids, with the exception of drops or syrups consisting of vitamins, minerals supplements, or medicines. Exclusive breast milk is adequate in quality as well as in quantity in terms of nutrition, immunity and protecting from various infections for an infant's need under six months. WHO and UNICEF recommend that all mothers should breastfeed their children exclusively for the first 6 months and thereafter they should continue to breastfeed for as long as the mother and child wish, and both appropriate and sufficient weaning food should be added after six months of life. According to 2013 figures published in the Lancet, suboptimal breastfeeding alone increases the risk of child mortality, annually resulting in 800,000 deaths worldwide [15-17].

Trend data suggests that, the prevalence of exclusive breastfeeding among infants younger than six months in developing countries increased from 33\% in 1995 to 39\% in 2010. The prevalence increased in almost all regions in the developing world, with the biggest improvement seen in West and Central Africa where the prevalence of exclusive breastfeeding has increased more than double from $12 \%$ in 1995 to $28 \%$ in 2010. Eastern and Southern Africa countries also realized improvements with an increase from $35 \%$ in 1995 to $47 \%$ in 2010. More modest improvements were observed in South Asia (40\% in 1995; 45\% in 2010). In Ethiopia, various studies showed a $52 \%$ prevalence of exclusive breastfeeding, which is better than any other sub Saharan African countries. However, still the coverage of exclusive breastfeeding observed is suboptimal, which is far below the target (90\%) set by WHO. So to scale up exclusive breastfeeding rate, effective programs such as establishing donor human milk bank in health settings are crucial.

\section{Prevalence of Low Birth Weight}

Low birth weight has been defined by the $\mathrm{WHO}$ as, weight at birth of less than 2,500 grams (5.5 pounds) [18]. Every year more than 20 million infants worldwide, representing $15.5 \%$ of all births are born with low birth weight, and 95.6 per cent of them lived in developing countries.

Among the developing countries, South and Central Asia represents half of all low birth weight. Low birth weight levels in sub-Saharan Africa are around 15\%. Central and South America and the Caribbean on average, have much lower rates of low birth weight (10\% \& 14\% respectively). Available studies in Ethiopia showed rate of low birth weight to be $11.4 \%$ in Addis Ababa [19], 17.4\% in Gondar [20], and $22.5 \%$ in Jimma [21] area. In addition, WHO estimated a $14 \%$ prevalence of low birth weight in Ethiopia [22].

Low birth weight is closely associated with fetal and neonatal mortality and morbidity, inhibited growth and cognitive development. In addition, it is linked to chronic diseases such as diabetes, hypertension, and heart disease later in life. To reduce such complication WHO set a goal; which aim to reducing low birth weight by at least one third; but still the prevalence of low birth weight remain high especially in developing countries like Ethiopia [18].

\section{Infant and Neonatal Mortality Rate}

Overall, substantial progress has been made towards achieving Millennium Development Goal (MDG 4). This is mainly because of improvement in maternal, child and public health interventions. The number of under-five deaths worldwide has declined; however, still globally 8 million infants (before their first year of age) die each year. This is because the death that occur within first month of life (neonatal age) has increased by 19\% since 1900 from 37\% to $44 \%$. Death that occurs in the first month (neonatal age) 
is about 4 million each year. Among this, the highest death (3 million) occurs in the first week of infant life. This clearly indicates that, intervention at neonatal age is one of the most critical strategies to reduce overall child mortality and morbidity [13].

In developing countries, the risk of death in the neonatal period is six times greater than in developed countries. Globally, 41 neonatal deaths occur per 1000 live births. The risk of neonatal death in Africa is the highest specially in Sub Saharan region which is between 37 and 49 per 1000 live birth. Since 2005, neonatal death in Ethiopia remains at 37 death per 1000 live birth [13,14].

Reducing neonatal deaths is, therefore, an essential step towards reducing under five mortality; Having all babies access to exclusive breastfeeding alone reduces the neonatal death, especially the death that occur soon after birth by $13 \%[13]$.

\section{Preterm Birth}

Preterm birth is defined by WHO as, all births before 37 completed weeks of gestation or fewer than 259 days since the first day of a woman's last menstrual period [23]. Globally, about 15 million babies were born too early, representing a preterm birth rate of $11.1 \%$. Over $60 \%$ of preterm births occurred in sub-Saharan Africa. In addition, in South Asia about 9.1 million births annually are estimated to be preterm. The high absolute number of preterm births in Africa and Asia are related, in part, to high fertility rate and the large number of births. Preterm birth is a major cause of death and a significant cause of long-term health complication impairing neurodevelopmental functioning, learning impairment, visual disorders and affecting longterm physical health with a higher risk of non-communicable disease amongst survivors all around the world $[23,24]$.

Complications of preterm birth are the single largest direct cause of neonatal deaths, responsible for 35\% of the world's 3.1 million deaths a year, and the second most common cause of under- 5 deaths after pneumonia. Therefore, addressing preterm birth is essential for accelerating progress towards MDG 4 [24].

\section{Clinical Benefit of Breast Milk for Infants}

Reducing Risk of Respiratory Tract Infections and Otitis Media: The risk of hospitalization for lower respiratory tract infections in the first year can be reduced by $72 \%$ if infants are breastfed exclusively for more than 4 months. The severity of respiratory infection is reduced by $74 \%$ in infants who breastfed exclusively for 4 months compared with infants who never or only partially breastfed. Exclusive breastfeeding for more than 3 months reduces the risk of otitis media by $50 \%$. Serious colds and ear and throat infections can be reduced by $63 \%$ in infants feeding breast milk exclusively than who feed exclusively infant formula or a combination of breastfeeding and infant formula $[25,26]$.

\section{Reduces Risk of Gastrointestinal Tract and Necrotizing} Enter Colitis Infections: Any breastfeeding is associated with a $64 \%$ reduction in the incidence of nonspecific gastrointestinal tract infections as compared to feeding commercial infant formula for the first six month of life [27]. Meta-analyses of 4 randomized clinical trials performed over the period 1983 to 2005 supports the conclusion that feeding preterm infants human milk is associated with a significant reduction (58\%) in the incidence of necrotizing enter colitis NEC. A more recent study of preterm infants fed an exclusive human milk diet compared with those fed cow-milk- based infant formula products noted a 77\% reduction in NEC [25]. Breastfeeding is associated with a $31 \%$ reduction in the risk of childhood inflammatory bowel disease [28].

Obesity and Diabetes: There is a $15 \%$ to $30 \%$ reduction in adolescent and adult obesity rates if any breastfeeding occurred in infancy compared with no breastfeeding. The Framingham Offspring study noted a relationship of breastfeeding and a lower BMI and higher high-density lipoprotein concentration in adults [29]. Up to a $30 \%$ reduction in the incidence of type 1 diabetes mellitus is reported for infants who exclusively breastfed for at least 3 months by avoiding exposure to cow milk protein infant formula $[30,31]$.

Neurodevelopmental Outcomes: Consistent differences in neurodevelopmental outcome between breastfed and commercial infant formula-fed infants have been reported. Higher intelligence scores are noted in infants who exclusively breastfed for 3 months or longer and higher teacher ratings were observed if exclusive breastfeeding was practiced for 3 months or longer. Significantly positive effects of human milk feeding on long-term neurodevelopment are observed in preterm infants, the population more at risk for these adverse neurodevelopmental outcomes [31].

Nutritional and Health Benefits of Donor Human Milk for Premature Infants: Pasteurized Donor Human Milk Banking is a specialized service which screen milk donors, collect, process, and store and dispense breast milk by physician order or prescription to the needy Infants who are not biologically related to donor mothers. Because of its proven benefit, WHO ranks Donor human milk as the second best choice after mother's own breast milk for feeding new born infants [32]. Although some of these nutrients and biological properties change with storage and heat treatment (pasteurization) there is good evidence that pasteurized and 
stored human milk could be safe, it maintains its unique qualities, such that it continues to be the gold standard for infant feeding, and superior to artificial feeding allowing provision of optimal nutrition to the child when mother own or immediately expressed milk is not available [10].

Maternal Outcomes of Breastfeeding: In addition to its benefit to baby, breastfeeding also have significant benefit to mothers. Both short- and long-term health benefits improved, to mothers who breastfeed. Such mothers have decreased postpartum blood loss. Continued breastfeeding leads to increased child spacing. In addition, breastfeeding duration was associated with a decreased risk of type 2 diabetes mellitus; for each year of breastfeeding, there was a decreased risk of diabetes mellitus by $4 \%$ to $12 \%$ [33]. An association between cumulative lactation experience and the incidence of adult cardiovascular disease was reported by the Women's Health Initiative in a longitudinal study of more than 139, 000 postmenopausal women [34]. Cumulative duration of breastfeeding of longer than 12 months is associated with a $28 \%$ decrease in breast and ovarian cancer [35].

\section{Hierarchy of Feeding Low Birth Weight and Premature Infants}

\begin{tabular}{|c|c|c|}
\hline Best & $\begin{array}{l}\text { Mother's own } \\
\text { Milk }\end{array}$ & $\begin{array}{l}\text { Helps bonding, good balance of nutrients } \\
\text { Easily digestible, support normal gut development } \\
\text { Prevents general infections and those to which mother is exposed in the baby's environment }\end{array}$ \\
\hline & $\begin{array}{l}\text { Donated fresh } \\
\text { preterm milk }\end{array}$ & $\begin{array}{l}\text { Good balance of nutrients, easily digestible } \\
\text { Prevents general infections and those to which mother is exposed but not from baby's } \\
\text { environment, support normal gut development }\end{array}$ \\
\hline & $\begin{array}{l}\text { Donated fresh } \\
\text { term mature milk }\end{array}$ & $\begin{array}{l}\text { Prevents general infections } \\
\text { Easily digested, but may lack(s) adequate protein, and fat Supports normal gut development }\end{array}$ \\
\hline & $\begin{array}{l}\text { Pasteurized } \\
\text { donated human } \\
\text { milk }\end{array}$ & $\begin{array}{c}\text { Immunologic factors are variously affected: secretory IgA, bifid growth } \\
\text { factor and lysozyme (0-30\% destroyed), lactoferrin ( } 57 \% \text { destroyed) and } \\
\text { IgG ( } 34 \% \text { destroyed) so may be less effective in fighting certain infectious } \\
\text { Agents than breastfeed } \\
\text { May support normal gut development } \\
\text { HIV, human T-lymphotrophic virus, CMV and many other bacteria, viruses destroyed } \\
\text { Easily digested }\end{array}$ \\
\hline & Preterm formula & $\begin{array}{l}\text { Nutrients adapted to special needs but do not replicate human milk Not easily digestible as } \\
\text { human milk, no immunological properties Increased risk of severe reactions and infections } \\
\text { Does not support normal gut development }\end{array}$ \\
\hline Worst & $\begin{array}{l}\text { Ordinary } \\
\text { Formula }\end{array}$ & $\begin{array}{l}\text { Wrong balance of nutrients } \\
\text { No immunologic properties, and therefore increased risk of severe reactions and infections } \\
\text { Difficult to digest and does not support normal gut development }\end{array}$ \\
\hline
\end{tabular}

Table 1: WHO Hierarchy of Feeding Priority for new born infants [36].

\section{Promoting Breastfeeding Through Human Milk Banks}

The purpose of the human milk banking service is protecting, promoting and supporting exclusive breastfeeding by filling the gap, when infants are unable to get from own mother breast milk. In addition, the presence of DHM service in health facilities increases mothers and health professionals awareness of the importance of breastfeeding and subsequently improves breastfeeding practices and rates. Study shows that; the exclusive breastfeeding rates for infants upon discharge from hospitals where DHM service available were significantly higher (29.6\%) compared with those hospitals without HMB service (16.0\%) [37].
A comprehensive approach is needed to promote exclusive breastfeeding and increase awareness among prospective donors and recipients while ensuring access to donor milk. Establishing an HMB can help to develop an integrated system for providing optimal newborn care, building on the MBFI approach, and provide a solid foundation to promote breastfeeding, kangaroo mother care (skin-to-skin contact), and other best practices for neonatal care. One mechanism for doing this is integration of DHMB service into existing newborn care systems, which provide a solid foundation to promote breastfeeding and other best practices. Additionally, establishing services such as BFHI/ MBFI and the WHO International Code of Marketing of Breast-milk Substitutes (ICMBMS) also are critical steps on ensuring exclusive breastfeeding [37,38]. 


\section{Storage Guideline and Bacteriological Safety of Expressed Breast Milk}

Both expressions of human milk at home, at health settings and at DHMB settings require the storage of human milk, and thus there is a need for human milk storage guidelines. These recommendations are based on a clinical protocol written by the Academy of Breastfeeding Medicine $(\mathrm{ABM})$ protocol committee. Storage durations suggested in the protocol is based on studies examining bacterial growth of human milk during storage, or the bacterial load of expressed human milk. This emphasize the importance of considering bacteriological properties when reviewing the human milk storage in order to prevent spoilage and ensure the bacteriological safety and quality of human milk [39].

In addition, to ensure the bacteriological safety of human milk, bacteria types that are highly associated with infant infections shall be considered as critical factors. Enterobacteriaceae are the most common micro flora found in human's lower intestine. Even though most are strain harmless, some can cause infections or even produce poisons. Another main pathogenic bacterium that can cause infant meningitis is Staphylococcus aureus. Furthermore, Staphylococcus aureus is also one of the most common causes of bloodstream infections, which can lead to serious complications among infants. Thus, in addition to total coliform count and aerobic plate count, Entrrobacteriaceae and Staphylococcus aureus are also of interest in our study in order to ensure a bacteriological safe condition in human milk banking [40].

Based on the guideline of The ABM and Centers for Disease Control and Prevention(CDC), (Table 2) human milk can be stored 6-8 hours at room temperature, 8 days under refrigerator $\left(2\right.$ to $\left.8^{\circ} \mathrm{C}\right)$ and $3-12$ months under frozen storage $\left(-4\right.$ to $\left.-20^{\circ} \mathrm{C}\right)$. Although, unpasteurized stored human milk may have an altered smell and taste because of the activity of intrinsic enzymes. However, in pasteurized breast milk, the combination of pasteurization and freeze storage minimize the rate and extent of deterioration of nutrients, by enzymes and microorganisms, and thus maintain the quality of stored breast milk [39-41].

\begin{tabular}{|c|c|c|}
\hline Location of storage & Temperature & Maximum recommended storage duration \\
\hline \multirow{2}{*}{ Room temperature } & $16-29^{\circ} \mathrm{C}\left(60-85^{\circ} \mathrm{F}\right)$ & $3-4$ hours optimal \\
\cline { 3 - 3 } & & $6-8$ hours acceptable under very clean conditions \\
\hline \multirow{2}{*}{ Refrigerator } & $\leq 4^{\circ} \mathrm{C}\left(39^{\circ} \mathrm{F}\right)$ & 72 hours optimal 5-8 days under very \\
\cline { 3 - 3 } & $<-4^{\circ} \mathrm{C}\left(24^{\circ} \mathrm{F}\right)$ & clean conditions \\
\cline { 3 - 3 } & Freezer & $3-6$ months optimal \\
\hline
\end{tabular}

Table 2: Milk Storage Guidelines [39-41].

\section{History and Distribution of Donor Human Milk Banking}

Historian records showed, 1909 as the year which witnessed the first milk bank opened in Vienna, Austria. Since then, the phenomenon of milk banking has witnessed different ups and downs throughout time. Early in the 20th century, milk banking blossomed and grew with increased use of donor milk for ill and premature infants. In 1943, the American Academy of Pediatrics (AAP) created guidelines for milk banks which are now enforced by the Human Milk Banking Association of North America [42].

With the advent of HIV/AIDS in the mid-1980s, the number of milk banks shrank dramatically due to people's concern about possible infections. By the 1990s, with evidence of safety and increased research on the benefits of human milk, DHMB were again expanding globally. Different researchers have now enumerated the various benefits of
DHMB service. Provision of donor milk continues today as an effective strategy for promoting the benefits of breast milk and saving newborns 'lives.

Currently, there are 13 established and 2 developing human milk banks in North America, 203 active and 13 planned milk banks in Europe and 220 human milk banks and 113 collection centers in Brazil. In Africa, fully functioning human milk banking established only in South Africa [21].

Despite its long history in its use, yet the majority of vulnerable infants around the world specially in developing countries who are in need of this lifesaving intervention do not have access to it, largely due to lack of knowledge, awareness, supportive policy, leadership and resources [42].

\section{Challenges in Human Milk Banking}

A more widespread use of PDHM is limited because 


\section{Food Science \& Nutrition Technology}

of concerns and challenges by the mothers and health professionals. One of the major concerns is the lack of knowledge about the safety of PDHM during processing. Additionally, concern may arise due to transfer of infectious disease such as HIV/AIDS from donor women to baby. Also, pasteurization, and less importantly, handling and storage partially affect the nutritional and biological components of human milk. Moreover, as breast milk is body fluid provided for baby from other women, acceptability by the mother's, health professionals and community is not easy. Promotion of infant formula in the health facilities is also another challenge, especially in countries who did not sign International Code of Marketing Breast Milk Substitute (ICMBMS). Lack of knowledge, awareness, leadership, commitment of health professional in promoting and protecting exclusive breastfeeding is also additional challenges [43-46].

A qualitative study was conducted in South Africa, Durban public hospital in 2011 to analyze the attitude of mothers, families and health care providers of potential recipient infants; although breast milk was seen as important to child health, there was concern of feeding breast milk because of disease transfer specially HIV/AIDS and promotion and marketing infant formula in health settings. The finding generalizes that obstacle to the acceptability of donor human milk mainly was from lack of awareness or familiarity with the process around donor breast milk [47].

A quantitative cross-sectional study was conducted in Nigeria Teaching Hospital to assess mothers' perception of the use of banked human milk. Result showed that $51 \%$ of them had heard of breast milk banking mainly from health professionals. Majority of them $84.8 \%$ of mothers would not give their child human milk mainly because of fear of transfer of infectious disease; however $59.1 \%$ strongly agreed that human milk banking would help assist mothers in need [48].

\section{Regulation of Donor Human Milk}

Regulation of human milk banking is based on its distinct characteristic from other food products. On one hand, human milk considered as a food for new born infants that contains the appropriate amounts of nutrients, immunological and protective substances to help infants for optimal growth and development as well as resist infections. Also human milk is considered as nutrition therapy that intended for the specific dietary management of a disease or condition for which distinctive nutritional requirements are established by medical evaluation. Additionally; human milk is considered as tissue; as it is body fluid with full of live cells. By considering its unique nature, most of countries establish a human milk regulatory body which serves as a liaison between member institution and government regulatory agency; and preparing comprehensive guidelines that address the processing of donor milk [42-49].

\section{Processing of Donor Human Milk}

According to the guideline of HMBANA, the process of human milk banking starts with selection and screening of breast milk donors. Generally, lactating mothers, whose baby is less than one year, are eligible for donation. Although screening criteria in each setting must be tailored to local concerns and needs, it is suggested that the general guidelines outlined should be followed to help ensure quality and safety of human milk. As a general rule, the breast milk donating mothers should provide informed written consent for their participating in DHMB service. In addition, mothers should be screened for the presence of infection, drug, tobacco and regular alcohol consumption [42].

\section{Serologic Testing}

In addition to screening, $\mathrm{HMB}$ service request serologic testing from donors to screen for hepatitis B or C, syphilis, HIV type 1 or 2, HTLV type I or II, and other diseases occurring in the area that may be transmitted in donated milk. A donor is excluded if she uses tobacco products, including nicotine patches and gum, drinks excessive quantities of alcohol, takes medications contraindicated during breastfeeding, or tests positive for any of the aforementioned viruses [42].

\section{Laboratory Testing of Donated Human Milk}

After human milk is collected from donors, each sample of human milk tested for its total bacterial count, Enterobacteriaceae and Staphylococcus aureus and the milk will be discarded if the bacterial count exceeds $5 \log 10 \mathrm{CFU} /$ $\mathrm{ml}$, for the total bacterial count and $4 \log 10 \mathrm{CFU} / \mathrm{ml}$ for Enterobacteriaceae and Staphylococcus aureus. In addition, after the breast milk is pasteurized to inactivate bacteria, viruses, and other potential pathogens while limiting the impact on the milk's nutritional and protective elements, such as proteins, antibodies; total bacterial count, Entrobactericia and Staphylococcus aureus tests is suggested and pasteurized milk must be discarded if any microbial count is detected [49].

\section{Effects of Pasteurization, Storage Time and Storage Temperature on the Constitute of Expressed Human Milk}

Effects of Storage on Macronutrient of Breast Milk: Though protein constitutes only about $10 \%$ of the dry matter, it plays critical roles in human growth, development and metabolism. Furthermore, immune active proteins in human milk were also reported to develop the baby's immune defense system. Various studies on the stability 


\section{Food Science \& Nutrition Technology}

of nutritional protein and immune active compounds has confirmed that, nutritional and immunological protein can be stored in refrigerated storage for 96 hours and in frozen storage for 3 months $[50,51]$.

Study on the lipid stability of human milk showed that, free fatty acid levels in human milk increased with the length of storage and with increased temperature. However, it was suggested that, modest formation of free fatty acid during storage in deep freezing condition may be beneficial to the baby of scares lipolytic enzymes [52].

Study suggested that, decrease in carbohydrates have been found at different storage conditions including ambient temperature storage $\left(29^{\circ} \mathrm{C}\right)$ after 3 hours, refrigerated storage $\left(4^{\circ} \mathrm{C}\right)$ over 96 hours and frozen storage $\left(-20^{\circ} \mathrm{C}\right)$ over 180 days [53]. The decline might have been caused by the activity of bacteria during storage, which converts the main sugar, lactose, to lactic acid by anaerobic glycolysis [54].

In the study of the effect of storage duration and temperature on the vitamins concentration of expressed pasteurized breast milk, Moffatt examined that no significant differences were observed during 24 hour of refrigerated storage and 3 month frozen $\left(-20^{\circ} \mathrm{C}\right)$ storage. However, significant loss of vitamin $\mathrm{C}$ was reported $[55,56]$.

\section{Bacteria Activity During Storage}

Expressed human milk is easily contaminated by bacteria from maternal skin and the surrounding environment. Inadequate sanitation and improper storage can result in bacterial contamination and threaten infant health. Studies found that pathogenic bacteria can cause severe infant infections including diarrhea, meningitis and bloodstream infections to name a few [57]. Therefore, it is of great importance to understand the bacteriological status of expressed human milk during storage and thus ensure proper milk handling procedures. Even though it is found that most bacterial species isolated from expressed human milk were normal skin flora including staphylococci, streptococci and some lactic acid bacteria, there are also pathogenic bacteria that contaminate expressed human milk [58]. However, bacterial growth was suppressed in expressed and pasteurized human milk stored at different storage temperature for definite period of time. Various study showed that, in expressed and pasteurized human milk, no increase in bacteria level was observed up to 8 hours at room temperature, 5 days in refrigerator and 12 weeks at frozen $(-20)^{\circ} \mathrm{C}$ storage [59].

In a study of safety of feeding infants from donor human milk bank; feeding and morbidity data was collected to determine if there were any adverse events associated with donor human milk. The finding showed that there was no evidence of bacterial contamination in the samples analyzed and no evidence of adverse events from feeding was detected [47].

An experimental study was conducted to evaluate the effects of cold storage on the natural bacterial composition of breast milk stored at $-20^{\circ} \mathrm{C}$ for six weeks; breast milk from 34 healthy mothers were collected and plated on to several culture media. The finding showed that no statistical difference was observed between the count obtained at both sampling time (first day and after six weeks). The predominant bacteria in both fresh and frozen samples were coagulase negative Staphylococcus, Staphylococcus aureus and streptococci species. The finding concluded that cold storage of human milk at $-20^{\circ} \mathrm{C}$ for six weeks does not significantly affects either the quantitative or the qualitative bacterial composition of breast milk [60].

An experimental study was conducted to examine the bacteriological safety of human milk storage in Japan in 2013 which was stored in freezer $\left(-20^{\circ} \mathrm{C}\right)$ for four weeks. Result showed that no statistical difference in bacterial count of fresh and stored sample was observed. Coagulase negative Staphylococcus, Staphylococcus aureus and Escherichia Coli were the predominant bacterial species isolated. The bacterial count was range, from 3 to $4 \log$ but do not exceed 5*105 [61].

An experimental study was conducted in Brazil 2008, to verify the existence of a relationship between the presences of off-flavor and microorganism load of expressed and banked human milk. Result showed that there is a consistent relationship between presence of off-flavor and elevated microorganism counting in the analyzed samples [62].

\section{Material and Methods}

\section{Ethical Consideration}

Ethical approval was obtained from Institutional Review Board of College of Natural Science and Tikur Anbessa Specialized Teaching Hospital of Addis Ababa University. After the purpose of the study was explained to study participants; written consent (Annex A) was obtained from all participants.

\section{Study Design}

An institutional based descriptive cross sectional study was conducted to analyze the knowledge and attitude of mothers and health professional from Addis Ababa towards the use of pasteurized donor human milk banking. In addition, laboratory based research design was used to examine the 


\section{Food Science \& Nutrition Technology}

microbiological safety, fat and protein content and sensory quality of expressed breast milk stored for two months.

\section{Study Area}

The present study was conducted in hospitals provide maternal and child health service; Tikur Anbessa Specialized Teaching Hospital, Yekatit Asrahulet hospital, Gandih Mimorial Hospital, Dinberua Mother and Child Hospital and Ethio Tebib General Hospital.

\section{Study Population}

The study populations were mothers attending pediatrics and obstetrics and gynecology ward in the Tikur Anbessa Hospital Yekatit 12 hospital, Gandih Mimorial Hospital, Dinberua Mother and Child Hospital and Ethio Tebib General Hospital for their antenatal, postnatal and child care service; and health professionals who were working at pediatric and obstetrics departments department of selected hospitals

\section{Sample Size Determination}

The number of participants is calculated following a single population proportion formula as indicated below.

$$
\mathrm{n}=\frac{(\mathrm{Z} \alpha / 2)^{2} \mathrm{P}(1-\mathrm{P})}{\mathrm{d}^{2}} ; \quad \mathrm{n}=\frac{1.96^{2 *}(0.5)^{2}}{0.05^{2}}=384+5 \%=402
$$

Where

- $\mathrm{n}$ is the required sample size

- $(\mathrm{Z} \alpha / 2) 2$ critical value at $95 \%$ certainty (1.96)

- $\quad$ Proportion $(\mathrm{P})=$ anticipated proportion of mothers and health professionals having optimum knowledge, or attitude to pasteurized human milk and $50 \%$ is taken due to absence of reliable previous study.

- $\mathrm{d}=$ margin of error $(0.05)$

- Level of significance $=0.05$

\section{Sampling Procedure}

Hospitals that provide maternal and child health service were stratified in governmental and private. Then, three public and two private hospitals were selected for data collection. Mothers who were attending antenatal and postnatal care and health professionals who work in the study hospitals for the period of December, 2014 to October, 2015.

Inclusion Criteria: Mother who attending obstetrics and pediatrics unit for antenatal, postnatal or child care service and mothers who are available at the time of data collection. Mothers with sever health complication were excluded from the study.

Inclusion Criteria for Health Professionals: Health professionals who worked in pediatrics, gynecology and obstetrics unit of selected hospitals and available at the time of data collection were included in the study.

Study period: December 2014-October, 2015

\section{Data Collection}

Semi-structured questioner was used to collect data on socio-demographic characteristic, practice of antenatal and postnatal care service and counseling about infant feeding and exclusive breastfeeding; knowledge of exclusive breastfeeding; knowledge and attitude of mothers and health professionals about donor human milk banking; breastfeeding problems encountered and their alternative feeding when unable to breastfeed. The questionnaires were prepared by investigator, modified after pilot testing, translated in to Amharic for data collection and then to English again for data reporting.

\section{Breast Milk Sample Collection}

A total of $20 \mathrm{ml}$ of breast milk sample from each randomly selected 26 healthy, lactating mothers attending postnatal and child health care. All mothers received verbal instruction on how to wash their hands and the nipple part using distilled water to avoid contamination. Moreover the nipple part was cleaned with clean cotton swab. Sample collection was with the help of pediatric nurses who wore sterilized gloves to avoid cross contamination. All samples were expressed by manual expression and collected in sterile polyethylene plastic bottles and kept in ice box.

The collected breast milk samples were transported to Addis Ababa University, Center for food Science and Nutrition, Food and Microbiological Laboratory with in 4 hour after sample collection using ice box. The samples were then stored in a refrigerated at temperature of $-20^{\circ} \mathrm{C}$.

\section{Laboratory analysis}

Microbiological Analysis: From 26 mothers expressed breast milk 10 of them fulfill the criteria set by HMBANA [42], thus in this study a total of 10 milk sample were used for microbiological analysis. First, each $20 \mathrm{ml}$ of milk samples were divided in to 2 aliquot. To study microbiological safety sensory quality, half of the samples were pasteurized on water bath at $62.5^{\circ} \mathrm{C}$ for 30 minutes and half of each sample was kept raw and stored in a refrigerator at $8-200^{\circ} \mathrm{C}$ Then, each pasteurized and raw milk samples were divided in to five equal portion and labeled with (P1, P2, P3, P4, P5) for 
paste urized breast milk and (R1, R2, R3, R4 and R5) for raw breast milk. The first two samples (P1 and R1) were analyzed immediately after pasteurization and the rest samples were stored in deep freeze (below negative four degree Celsius) for further analysis. The second two samples (P2 and R2) were analyzed at $7^{\text {th }}$ day, the third two samples (P3 and R3) at 15th day, the fourth two sample (P4 and R4) at 30th day the last two samples (P5 and R5) analyzed at 60th day after deep freeze storage (Figure 1).

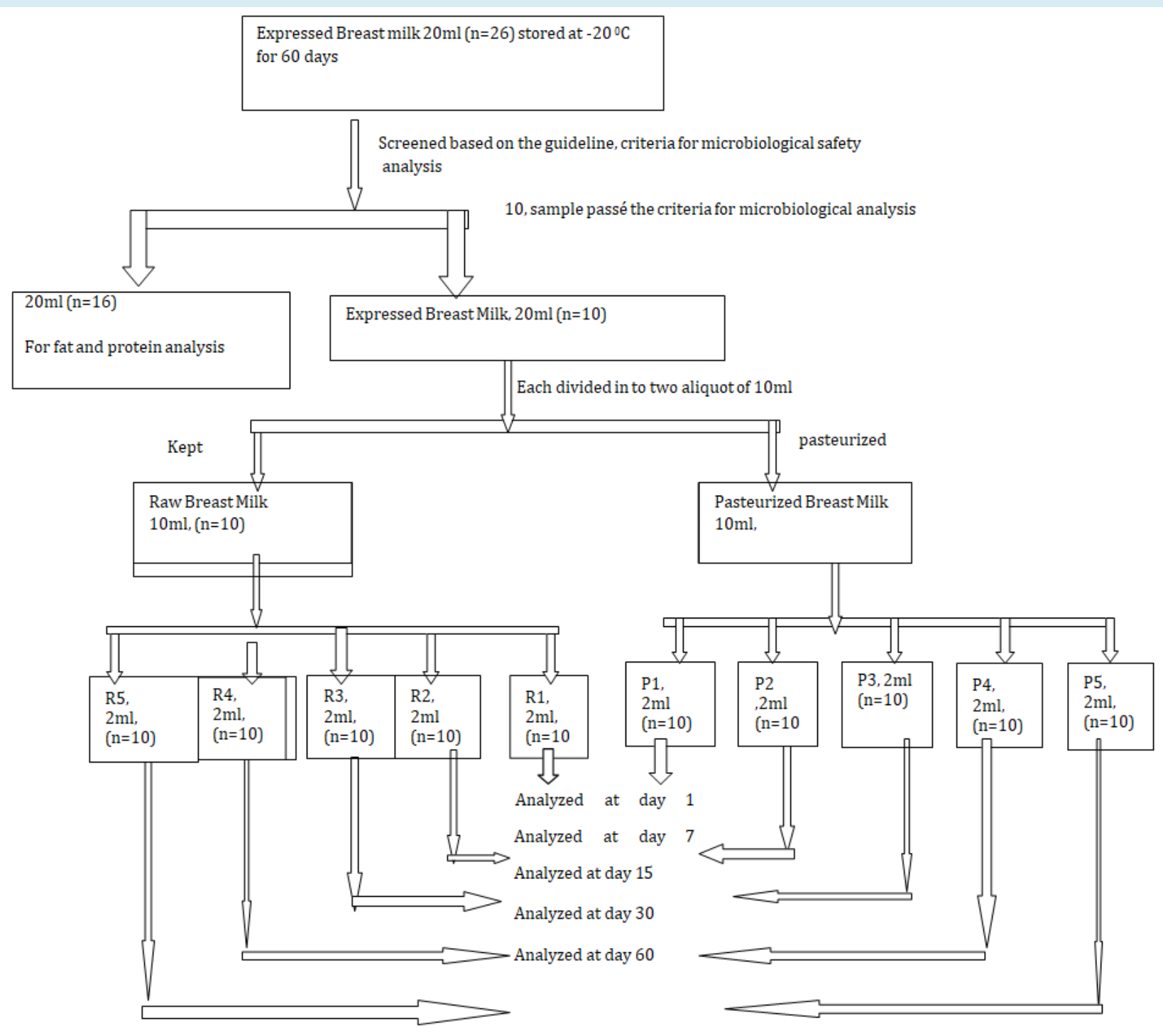

Figure 1: Screened based on the guideline, criteria for microbiological safety analysis.

Culture Media Preparation: Based on the guideline of HMBANA [42], the culture media used for growth isolation and identification of bacteria of interest included nutrient agar for total aerobic count, MacConkey agar for isolation of Entrobacteriaceae and mannitol salt agar for identification of pathogenic Staphylococcus aurous.

Preparation of Culturing Media Agar: About $28 \mathrm{gm}$ of nutrient agar powder was dissolved in 1 litter of distilled water; the mixture was heated while stirring until all the powder dissolved.Similarly, for the preparation of MacConkey agar, 50 gm of MacConkey agar powder was dissolved in 1 litter of distilled water and for manitol salt agar111 gm of manitol salt agar powder was dissolved in 1 litter of distilled water then the dissolved mixture was autoclaved at 121 degrees Celsius for 15 minutes then cooled. After the prepared solid media was cooled, enough amount of each media was poured in to 33 previously autoclaved Petri dish. 
All beaker and glass test tubes also autoclaved.

Preparation of serial dilution: Five sterile glass test tube were prepared and labeled as 1,2,3,4 and 5. To each of glass test tube $9 \mathrm{ml}$ of distilled water was added. Then, from the original milk sample, after proper homogenization, $1 \mathrm{ml}$ sample was transferred to test tube 1 to make dilution, similarly $1 \mathrm{ml}$ from test tube 1 transferred to test tube $2,1 \mathrm{ml}$ from test tube 2 to test tube 3 , and finally $1 \mathrm{ml}$ from test tube 3 to test tube 4 to make a final dilution of $10-1,10-2,10-3$ and 10-4 respectively. Similarly, to test tube 5 (control test tube) $1 \mathrm{ml}$ distilled water was added [45].

Growth, Isolation and Identification of Microorganisms: On the autoclaved plate agar, $1 \mathrm{ml}$ of sample from 10-2, 10-3 and 10-4 dilution were inoculated and incubated at $37^{\circ} \mathrm{C}$ for 24 hour. In addition, $1 \mathrm{ml}$ distilled water from test tube 5 also inoculated. Colony counts were performed and the average count was expressed as viable Colony-Forming Units (CFU). Microbiological data were recorded in terms of colony forming unit per milliliter $(\mathrm{CFU} / \mathrm{ml})$ after translated to logarithmic form for analysis. Bacterial counts were compared at first day, seventh day, fifteen day, thyrtyth day and at sixty day among pasteurized and raw milk sample.

Chemical Analysis: For the chemical analysis, breast milk sample from 26 mothers were pooled together and a total of $300 \mathrm{ml}$ was made to analyze the average protein and fat content of breast milk. The sample was divided in to two aliquot of $150 \mathrm{ml}$. One aliquot was pasteurized and labeled as $\mathrm{P}$, the second aliquot was kept raw and labeled as R. Both aliquot were lyophilized. The milk powder obtained kept in plastic bag for analysis.

Analysis of Protein: Protein was determined by kjeldhal method based on the nitrogen determination. In this method, protein and organic food in the sample are digested with $\mathrm{H} 2 \mathrm{SO} 4$ in the presence of catalyst. Then the total organic nitrogen was converted to ammonium sulfate. The digest is neutralized with alkali and distilled in to a boric acid solution. The borate ion formed are titrated with standard $\mathrm{HCl}$, and converted to nitrogen in the sample [46].

Addition of Reagents: About 1gm sample was weighted in a tecator tube and placed in the tecator rack. Then $6 \mathrm{ml}$ of acid mixture was added by using pipette carefully and mixed with the sample immediately. Then $3.5 \mathrm{ml}$ of $\mathrm{H} 2 \mathrm{O} 2$ was added step by step until the reaction stop. As soon as the reaction ceased, the tube was hand shaken for few minutes and was put back in to the rack. $3 \mathrm{gm}$ of catalyst (k2so4 with a mixture of selenium) was added and the mixture was allowed to stand for 5-15 minute before the digestion.
Digestion: the tube in the rack was lowered in the digester in the fume hood at $370{ }^{\circ} \mathrm{C}$. the digestion was continuing until clear solution appeared ( 3 hour) in the fume hood. The total content of nitrogen was determined after titration using $0.1 \mathrm{~N} \mathrm{HCl}$.

Fat analysis: Fat was determined using soxhlet method. Fat was extracted with diethyl ether. And the solvent was evaporated from the extraction flask. The amount of fat was calculated from the difference in the weight of extraction cub before and after extraction [48].

The cleaned aluminum cup with boiling chips was dried at $92^{\circ} \mathrm{C}$ for an hour and cooled in the desiccators and weighted. Two gram of the sample was weighted in to the extraction thimble which was layered and covered with fat free cotton and attached the thimble to the magnetic ring to hang to the extraction chamber. Diethyl ether of $70 \mathrm{ml}$ was added to the aluminum cup through the condenser and soaked for an hour and let the extraction for three hour and twenty minute and finally the aluminum cup was removed. The extracted fat was dried in an oven for 30 minute and cooled in the desiccators and finally weighted. The extraction fat was calculated using the following formula

$$
\text { Crud fat }(\%)=\text { extracted fat/sample weighted }) * 100
$$

\section{Sensory Analysis}

The sensory quality of frozen breast milk was analyzed by duo trio method using 10 lactating mother, who were volunteer, can write and read after informed the purpose of the study, they provided with three breast milk sample; one reference, and two test sample (pasteurized and raw) and were asked to identify sample different from the reference (off-flavor).

\section{Result}

\section{Characteristics of Participants}

A total of 402; mothers $(n=320)$ and health professionals $(n=82)$ were included in the study. The socio-demographic characteristics of participating mothers are summarized in Table 3. About half ( $\mathrm{n}=163,50.9 \%)$ of participating mothers were Orthodox Christian. Most (n=218, 68.1\%) were married. From a total of health professionals participated in this study, $(n=16,19.5 \%)$ were pediatrician, $(n=22,26.8 \%)$ were gynecologist, $(n=18,22 \%)$ were general practitioners, $(\mathrm{n}=18,22 \%)$ were clinical nurse and $(\mathrm{n}=8,9.8 \%)$ were midwives. 


\begin{tabular}{|c|c|c|}
\hline Variable Description & Frequency & Percentage \\
\hline \multicolumn{3}{|l|}{ Religion } \\
\hline Orthodox Muslim & 163 & 50.9 \\
\hline \multirow[t]{2}{*}{ Protestant } & 79 & 24.7 \\
\hline & 78 & 24.4 \\
\hline \multicolumn{3}{|l|}{ Marital status } \\
\hline Single Married & 64 & 20 \\
\hline \multirow[t]{3}{*}{ Divorced Widowed } & 218 & 68.1 \\
\hline & 23 & 7.2 \\
\hline & 15 & 4.7 \\
\hline \multicolumn{3}{|l|}{ Age in year } \\
\hline$<20$ & 16 & 5 \\
\hline $21-35$ & 257 & 80.4 \\
\hline $35-39$ & 47 & 14.7 \\
\hline \multicolumn{3}{|l|}{ Education } \\
\hline $\begin{array}{c}\text { Uneducated Elementary } \\
\text { Secondary }\end{array}$ & 25 & 7.8 \\
\hline \multirow[t]{3}{*}{ Higher education } & 103 & 32.2 \\
\hline & 91 & 28.4 \\
\hline & 101 & 31.6 \\
\hline \multicolumn{3}{|l|}{ Occupation } \\
\hline House wife Self employed & 99 & 30.9 \\
\hline \multirow[t]{3}{*}{$\begin{array}{l}\text { Government employed } \\
\text { Private employed }\end{array}$} & 118 & 36.9 \\
\hline & 55 & 17.2 \\
\hline & 48 & 15 \\
\hline \multicolumn{3}{|l|}{ Number of children } \\
\hline One & 163 & 50.9 \\
\hline \multirow[t]{2}{*}{ Two Three } & 87 & 27.2 \\
\hline & 70 & 21.9 \\
\hline
\end{tabular}

Table 3: Frequency distribution of Socio-demographic characteristic of study mothers $(n=320)$.

As shown in Table 4 of the total study mothers, majority (90\%) attended antenatal and postnatal care at health facilities. However, only $63.4 \%$ of mothers obtained essential counseling on the subject of infant and young child feeding. Moreover, even less number of mothers $(50.6 \%)$ had proper counseling about the benefit of exclusive breastfeeding. More than half (63\%) of the study mothers experienced breast feeding problems to feed their new born baby. This was associated to the fact that, they (55\%) had lactation difficulty at the time of delivery or had health problem (45\%). In addition, about $64.7 \%$ of mothers responded that their new born baby was not able to breastfeed associated to health problem (71\%), prematurity (14\%) unable to latch on the breast (3.30\%). On such occasions, all study mothers reported that infant formula was their first alternative to exclusive breastfeed.

\begin{tabular}{|c|c|c|}
\hline Description of Variables & Frequency & Percentage \\
\hline $\begin{array}{c}\text { Percentage of mothers } \\
\text { attending antenatal care }\end{array}$ & 288 & 90 \\
\hline $\begin{array}{c}\text { Percentage of mothers } \\
\text { counseled about infant } \\
\text { feeding }\end{array}$ & 203 & 63.4 \\
\hline $\begin{array}{c}\text { Percentage of mothers } \\
\text { Counseled exclusive } \\
\text { breastfeeding }\end{array}$ & 162 & 50.6 \\
\hline $\begin{array}{c}\text { Percentage of mothers } \\
\text { encountered breastfeeding } \\
\text { problem }\end{array}$ & 202 & 63.1 \\
\hline $\begin{array}{c}\text { Percentage of new born baby } \\
\text { face breastfeeding problem }\end{array}$ & 207 & 64.7 \\
\hline $\begin{array}{c}\text { Mothers use Infant formula } \\
\text { as an alternative to } \\
\text { breastfeeding }\end{array}$ & 203 & 90 \\
\hline $\begin{array}{c}\text { Percentage of reason for } \\
\text { unable to breastfeed her baby } \\
\text { Have no enough milk }\end{array}$ & 111 & 55 \\
\hline $\begin{array}{c}\text { Health problem } \\
\text { Percentage of reason } \\
\text { new born baby unable to } \\
\text { breastfeed Health problem }\end{array}$ & 149 & 71 \\
\hline Prematurity & 47 & 14.7 \\
\hline Unable to latch on the breast & 11 & 5.3 \\
\hline
\end{tabular}

Table 4: Frequency distribution of mothers attending antenatal and postnatal care and counseled about infant feeding and exclusive breastfeeding $(\mathrm{n}=320)$.

Tables 5 explain our attempt to assess their knowledge on exclusive breastfeeding. About $47.5 \%$ of mothers correctly described exclusive breastfeeding. Even though, substantial number $(72.5 \%)$ of mothers know duration of exclusive breastfeeding, they considered that introduction of water during this time of breastfeeding is beneficial. In addition, majority of the mothers $(82.8 \%)$ know the health benefit of colostrum's for new born baby and long term health benefit of exclusive breastfeeding. About two third of study participants described the health consequence of feeding baby infant formula with in the first six month. Regarding donor human milk banking very few $(5 \%)$ of the participants 
knows or heard about it. Surprisingly none of them heard from health professionals at health facilities but all heard from mass media.

\begin{tabular}{|c|c|c|}
\hline Description of Variables & Frequency & Percentage \\
\hline Mothers describe exclusive breastfeeding correctly & 152 & 47.5 \\
\hline Mothers have knowledge of duration of exclusive breastfeeding & 232 & 72.5 \\
\hline Mothers have knowledge of health benefit of colostrums for baby & 265 & 82.5 \\
\hline Mothers knowledge on long term health benefit of EBF & 256 & 80 \\
\hline Mothers describe Health consequence of infant formula for baby & 226 & 70.6 \\
\hline Mothers knowledge of breastfeeding on mother child interaction & 280 & 87.5 \\
\hline Existence of donor human milk banking & 16 & 5 \\
\hline
\end{tabular}

Table 5: Frequency distribution of mothers attending antenatal and postnatal care and counseled about infant feeding and exclusive breastfeeding $(n=320)$.

As shown in Table 6, about attitude of mothers towards pasteurized donor human milk, very small percentage (3\%) of mothers like to feed their new born baby breast milk of another women even if mothers encounters difficulties to breastfeed. However, one fifth (20\%) of the study participants were volunteer to feed their baby donor human milk if doctor prescribe for them. In both cases the main reason for not interested to feed their baby was concern of safety or fear of transfer of disease (85.1\%) and to some extent, because of cultural or religious reasons $(11.7 \%)$. Two third of the mothers participated in the present study, expressed their willingness to donate their breast milk if human milk banking is established.

\begin{tabular}{|c|c|c|}
\hline Description of variables & Frequency & Percentage \\
\hline Mothers volunteer to feed baby breast milk from other women & 10 & 3 \\
\hline Mothers volunteer to feed baby donor human milk & 65 & 20.3 \\
\hline Mothers Volunteer to be member of human milk banking & 206 & 64.4 \\
\hline Mothers volunteer to donate breast milk to human milk banking & 211 & 65.9 \\
\hline Reason for not volunteer to feed donor human milk Safety or fear of transfer of disease & 217 & 85.1 \\
\hline Culture or religion prohibit feeding human milk & 30 & 11.7 \\
\hline Other reason (not suitable to feed) & 9 & 3.2 \\
\hline
\end{tabular}

Table 6: Frequency distribution of mothers attitude towards expressed human milk and pasteurized donor human milk (n=320).

\begin{tabular}{|c|c|c|c|c|c|c|}
\hline \multirow[t]{2}{*}{ Variables } & \multicolumn{6}{|c|}{ Volunteer to donor HM } \\
\hline & Yes & No & COR & P-value & AOR & P-Value \\
\hline Religion & 65 & 255 & & 0.005 & & 0.006 \\
\hline Muslim & 5 & 74 & 1 & & & \\
\hline Orthodox & 40 & 123 & 4.81 & 0.002 & 3.08 & 0.034 \\
\hline Protestant & 20 & 58 & 5.1 & 0.002 & 6.86 & 0.001 \\
\hline Marital status & 65 & 255 & & & & 0.019 \\
\hline Unmarried & 4 & 60 & 1 & & & \\
\hline Married & 54 & 164 & 4.94 & 0.003 & 3.76 & 0.027 \\
\hline Divorced & 2 & 21 & 1.43 & 0.693 & 0.55 & 0.548 \\
\hline Widowed & 5 & 10 & 7.5 & 0.007 & 3.04 & 0.189 \\
\hline
\end{tabular}

Table 7: Regression analysis of factor associated to attitude of mothers towards donor human milk. 
Food Science \& Nutrition Technology

As shown in Table 7, our regression analysis to identify factor predict attitude of mothers towards the use of pasteurized donor human milk shows that being Orthodox Christian had three times increase and being Protestant Christian had seven times increase in attitude towards the use of donor human milk. Others factors such as; age, occupation, marital status and number of live children were not significant $(\mathrm{P}>0.05)$ in predicting attitude of mothers towards the use of pasteurized donor human milk. Similarly, our regression analysis showed that; total knowledge of exclusive breastfeeding, encountered breastfeeding problem of both by mother and new born baby were not significantly determined the attitude of mothers towards pasteurized donor human milk $(\mathrm{P}>0.05)$.

Table 8 indicated that, Majority (90.2\%) of health professionals responded as they consistently provide counseling during antenatal and postnatal period on the subject breastfeeding. More than three forth of health professionals expressed their worries that promotion of infant formula could have negative impact on the rate of exclusive breastfeeding. In addition, $79.3 \%$ of them mentioned as there could be a direct relation on neonatal mortality and their feeding system. Surprisingly, more than half $(53.7 \%)$ of health professionals did not know or heard about donor human milk banking ever.

\begin{tabular}{|c|c|c|}
\hline Study variables & Frequency & Percentage \\
\hline $\begin{array}{c}\text { Percentage of counseling } \\
\text { about exclusive breastfeeding }\end{array}$ & 74 & 90.2 \\
\hline $\begin{array}{c}\text { Promotion of infant formula } \\
\text { has negative impact on } \\
\text { Exclusive breastfeeding }\end{array}$ & 62 & 75.6 \\
\hline $\begin{array}{c}\text { There is relationship between } \\
\text { infant feeding system and } \\
\text { neonatal mortality }\end{array}$ & 65 & 79.3 \\
\hline $\begin{array}{c}\text { Health professionals } \\
\text { knowledge about donor } \\
\text { human milk }\end{array}$ & 38 & 46.3 \\
\hline
\end{tabular}

Table 8: Frequency distribution of health professionals counseling practice of infant feeding and exclusive breastfeeding.

As shown in Table 9, three fourth of health professionals mentioned that establishing pasteurized donor human milk banking will reduce neonatal mortality and believed that establishing pasteurized donor human milk banking in their health setting could be possible. Slightly more than half (53.7\%) of them were willing to be a member of human milk banking and $96.3 \%$ to support the establishment of human milk banking and $96.3 \%$ could support the establishment of human milk banking professionally.

\begin{tabular}{|c|c|c|}
\hline Study variables & Frequency & Percentage \\
\hline $\begin{array}{c}\text { Establishing donor human } \\
\text { milk banking reduce neonatal }\end{array}$ & 5 & 4 \\
\hline Mortality and Morbidity & 61 & 74.4 \\
\hline $\begin{array}{c}\text { Volunteer to be member of } \\
\text { donor human milk banking }\end{array}$ & 44 & 53.7 \\
\hline $\begin{array}{c}\text { Volunteer to support donor } \\
\text { human milk banking if } \\
\text { established }\end{array}$ & 79 & 96.3 \\
\hline
\end{tabular}

Table 9: Frequency distribution of attitude of health professionals towards donor human milk.

As shown in Table 10 about $85.4 \%$ of health professionals participated in the study encounter at least once new born babies was not breastfeed. In addition, all of them encountered at least once that mothers who were not able to breastfeed. Prematurity (40.2\%), health problem (32.9\%), and congenital defect $(12.2 \%)$ were the main reasons for new born baby unable to breastfeed. All study participant's use or advice infant formula as alternative to breast milk.

\begin{tabular}{|c|c|c|}
\hline Study variables & Frequency & Percentage \\
\hline $\begin{array}{c}\text { Health professional } \\
\text { encounter new born baby } \\
\text { unable to breastfeed }\end{array}$ & 70 & 85.4 \\
\hline $\begin{array}{c}\text { Health professionals } \\
\text { encounter mothers unable to } \\
\text { breastfeed }\end{array}$ & 82 & 100 \\
\hline $\begin{array}{c}\text { Possible reason for baby } \\
\text { unable to breastfeed }\end{array}$ & 33 & 47.2 \\
\hline prematurity health problems & 27 & 38.5 \\
\hline congenital defect & 10 & 14.2 \\
\hline $\begin{array}{c}\text { Exclusive breastfeeding } \\
\text { substitute when infant } \\
\text { unable to breastfeed infant } \\
\text { formula }\end{array}$ & 82 & 100 \\
\hline
\end{tabular}

Table 10: Frequency distribution of health professionals encountered new born baby and mothers unable to breastfeed and first alternative to exclusive breastfeeding.

Majority of health professionals mentioned that, current trends such as; the government promotion of exclusive breastfeeding, health education of infant feeding and exclusive breastfeeding at health facilities, the increasing number of mothers attending antenatal, postnatal and child health care services and the increasing number of deliveries at health facilities considered as possible opportunities if pasteurized donor human milk banking will established. 
On the other hand, as the idea of donor human milk banking is new; resistance from the community, lack of knowledge about its safety and benefit, tradition or religion to some extent, ever increasing promotion of infant formula were mentioned as some prominent challenges for establishing the donor human milk banking. In addition availability of facilities such as electricity and trained manpower was also indicated as another challenge.

As indicated in Tables $11 \& 12$ in raw breast milk sample stored in deep freezer $\left(-20^{\circ} \mathrm{C}\right)$; total aerobic bacteria, Enterobacteriaceae, and Staphylococcus aureus were detected in the range of $4.48 \log 10 \mathrm{CFU} / \mathrm{ml}$ to $4.91 \log 10$ $\mathrm{CFU} / \mathrm{ml}, 3.00 \log 10 \mathrm{CFU} / \mathrm{ml}$ to $3.51 \log 10 \mathrm{CFU} / \mathrm{ml}$ and 3.32 $\log 10 \mathrm{CFU} / \mathrm{ml}$ to $3.58 \log 10 \mathrm{CFU} / \mathrm{ml}$ respectively from day 1 to day 60 of storage time. However, there was no statistically growth difference ( $\mathrm{p}>0.05)$ was observed from day 1 to day 60 storage time. in pasteurized breast milk samples stored in deep freezer $\left(-20^{\circ} \mathrm{C}\right)$ there was no bacterial growth was detected throughout storage time of 60 days. As shown in table 5. 10, both raw and pasteurized breast milk samples were with the acceptable range of the guideline of HMBANA [42].

\begin{tabular}{|c|c|c|c|}
\hline Storage duration & Bacterial type & growth range & Average growth \\
\hline \multirow{4}{*}{1} & Total aerobic count & $4.51-4.88$ & 4.65 \\
\cline { 2 - 4 } & Enterobacteriaceae & $3.02-3.48$ & 3.18 \\
\cline { 2 - 4 } & Staphylococcus aureus & $3.34-3.56$ & 4.48 \\
\hline \multirow{4}{*}{7} & Total aerobic count & $4.52-4.91$ & 3.21 \\
\cline { 2 - 4 } & Enterobacteriaceae & $3.00-3.49$ & 3.49 \\
\cline { 2 - 4 } & Staphylococcus aureus & $3.32-3.57$ & 4.66 \\
\hline \multirow{3}{*}{15} & Total aerobic count & $4.49-4.91$ & 3.21 \\
\cline { 2 - 4 } & Enterobacteriaceae & $3.00-3.49$ & 3.49 \\
\cline { 2 - 4 } & Staphylococcus aureus & $3.34-3.56$ & 3.68 \\
\hline \multirow{3}{*}{30} & Total aerobic count & $4.53-4.91$ & 3.5 \\
\cline { 2 - 4 } & Enterobacteriaceae & $3.00-3.51$ & 4.67 \\
\cline { 2 - 4 } & Staphylococcus aureus & $3.38-3.56$ & 3.28 \\
\hline \multirow{3}{*}{60} & Total aerobic count & $4.48-4.91$ & 3.5 \\
\cline { 2 - 4 } & Enterobacteriaceae & $3.00-3.52$ & $3.32-3.58$ \\
\cline { 2 - 4 } & Staphylococcus aureus & & \\
\hline
\end{tabular}

Table 11: Bacterial growth in raw breast milk sample stored at a temperature of $-20^{\circ} \mathrm{C}$ as a function of storage duration.

- Bacterial growth count was in $\log _{10} \mathrm{CFU} / \mathrm{ml}$

- $\quad$ Storage duration was in days (from day1 to day 60)

\begin{tabular}{|c|c|c|}
\hline Bacterial type & $\begin{array}{c}\text { Acceptable growth in raw } \\
\text { breast milk }\end{array}$ & Acceptable growth in pasteurized breast milk \\
\hline Total bacterial count & $<5 \log 10 \mathrm{CFU} / \mathrm{ml}$ & no growth of bacteria \\
\hline Enterobacteriaceae & $<4 \log 10 \mathrm{CFU} / \mathrm{ml}$ & no bacterial growth \\
\hline Staphylococcus aureus & $<4 \log 10 \mathrm{CFU} / \mathrm{ml}$ & no bacterial growth \\
\hline
\end{tabular}

Table 12: Acceptable bacterial growth range of raw and pasteurized donor breast milk [42].

In sensory analysis 10 lactating mothers participated and the result showed that, pasteurized milk samples have no significant changes with fresh expressed breast milk in terms of flavor. However the raw breast milk sample developed off flavor. The average protein content of raw expressed breast milk was $0.99 \mathrm{mg} / 100 \mathrm{ml}$, pasteurized breast milk
$0.98 \mathrm{mg} / 100 \mathrm{ml}$ and the average total fat content of raw breast milk was $2.00 \mathrm{mg} / 100 \mathrm{ml}$, pasteurized breast milk was $1.98 \mathrm{mg} / 100 \mathrm{ml}$. Statistical paired t test analysis showed that, there is no statistical difference $(p>0.05)$ found between pasteurized and raw proximate content of the sample 


\section{Discussion}

In Ethiopia the coverage of exclusive breastfeeding rate is about $52 \%$, which is still sub optimal and is far from universal coverage $\|$ target of $90 \%$ set by WHO [12]. On the other hand neonatal mortality rate in the country is high $[13,14]$. Having all babies access to exclusive breastfeeding reduces the neonatal mortality up to $13 \%$ [13]. Pasteurized donor human milk banking increase breastfeeding rate by filling the gap when new born baby is unable to breastfeed.

In our study, majority (95\%) of study mothers did not know the existence of donor human milk. Even, those (5\%) who heard about its existence, their source of information was not from health professionals but from mass media. This clearly indicated that, donor human milk bank is not current issue at health facilities. On the contrary, study in Nigeria showed that, about $25 \%$ of study mothers knew about the existence of donor human milk and their source of information was mostly from health professionals by education. So donor human milk is current issue that raised at health facilities which help Nigerian mothers for better understanding [66]. Generally the use of pasteurized donor human milk banking is limited to industrialized countries due to lack of enough knowledge of its nutritional and its health benefit for new born baby unable to breastfeed own mother. In Ethiopia, the idea of donor human milk banking is new, accordingly public education is crucial to increase knowledge about its safety and benefit.

After they have been provided some information about benefit of donor human milk banking, $20.3 \%$ of study mothers expresses their positive attitude towards donor human milk, suggesting the importance of promoting donor human milk banking for successful launching and establishment of the facility. Substantial number $(72.1 \%)$ of mothers in the present study expressed that they do not went to fed their new born babies donor human milk due to fear of transfer of disease. This finding was similar to previous study reports on the acceptability of donor human milk in south Africa [66], Nigeria [67], and Turkey [68], which undermine its use because of disease, specially HIV and due to lack of awareness or familiarity with the safe processing procedure of human milk banking.

In developing countries, acceptability of donor human milk by mothers and communities is not easy. Resent study in South Africa suggested that, the safety concern and lack of understanding was resolved by education of mothers and on service training of health professionals, advocating throughout government and media, large scale campaigning to promote breast milk donation and establishment of human milk banking association. Currently, in South Africa, more health professionals and mothers convinced of the safety of donor human milk and more vulnerable infants are now being offered donor human milk $[46,47]$. Even though screening of donor mothers and proper processing of donor breast milk for infectious and pathogenic microorganisms and particles is one mandatory activity, education of mothers, health professionals and communities with respect to the safety and benefit of donor breast milk is important [69-81].

In the present study, it was found that, nutrition and health education particularly about the subject matter of exclusive breastfeeding is provided regularly to mothers visiting health facilities for antenatal and postnatal care. However rate of exclusive breastfeeding of the country is suboptimal [12]. To scale up exclusive breastfeeding rate and to access all new born baby to breast milk, there must be an integrated approach service at health facilities. This integrated approach includes; developing breastfeeding policy at hospital level which includes ten steps for effective exclusive breastfeeding practice, establishing BFHI, establishing lactating supporting groups at community level and establishing donor human milk banking. Additionally, integration of the practice of pasteurized donor human milk in to mother and child health policy is the back bone for the successful practice of integrated approach systems. Currently, Brazil is one of the countries with high exclusive breastfeeding rate and can reduce its child mortality substantially and awarded by WHO. The secret of success is by integrating human milk banking in to mother and child health policy and applying all integrated approach system for effective breastfeeding practice [43]. Therefore the establishment of donor human milk banking could contribute to an increase rate of exclusive breastfeeding by filling the gap for those unable to breastfeed. Moreover, study showed that the presence of donor milk bank in a hospital, beside supplying directly human milk to needy infants, it increases communities'awareness of the importance of breastfeeding and subsequently improve breast feeding practice and rate [43].

Majority of health professionals express their worries that uncontrolled promotion of infant formula in health settings has negative impact on value of exclusive breastfeeding and undermine donor human milk. Similar concern was suggested in previous study in South Africa and Nigeria [43] [Fo7r9] example, in South Africa, health authorities took a decision not to provide free infant formula for new mothers at health facilities. Most industrialized countries implement international code of marketing breast milk substitute to protect mothers from marketing of infant formula (14). So implementation of the code will reduce the impact of the infant formula on exclusive breastfeeding and the value of donor human milk.

This finding showed that about $46.3 \%$ of health 
professionals participated in this study knew or heard about human milk banking. Previous study in South Africa reported also similar finding [47]. Majority (74.4\%) of health professionals believed that establishing pasteurized donor human milk banking will help vulnerable infants to reduce mortality and morbidity; but about one fourth of health professional participated in the study, who did not believed stated that, expressed and stored breast milk from another women may not be safe and nutritionally not effective as infant formula. More than three fourth of health professionals believed that it is feasible to establish pasteurized donor human milk bank in their health settings, however, about one fourth of study participants did not believe its feasibility due to concern such as; lack of enough infrastructure like electricity, lack of trained man power and convincing mothers, health professionals about its safety and may not be easy were among stated.

Current trends such as; awareness regarding benefit of exclusive breastfeeding, an increasing trends in the number of mothers attending antenatal and postnatal care and delivery at health facility and government promotion of exclusive breastfeeding can be considered as potential opportunities for the establishment of donor human milk banking.

Generally, establishing of pasteurized donor human milk bank is not easy. There should be strong commitment of health professionals, government authority, public and private media, religious leaders and others stake holders. Due to strong commitment of health professionals and government authorities, Brazil becomes global model on the service of donor human milk banking service. Currently the country has more than 220 donor human milk banks service at health facilities. Additionally, provide technical support of outreach program to more than 25 countries including Europe and Africa. In Brazil, any hospitals or health facilities, before establishing donor human milk banking service, first it must have its breastfeeding policy and designated fully as baby friendly [43].

The safety and quality of expressed and stored breast milk is depends on the bacterial load expressed breast milk or bacterial growth during storage. these bacterial contamination arises from mothers body or fecal contamination [39]. Even though pasteurization eliminate most pathogenic bacteria, to avoid enter toxin produced by pathogenic bacteria, the bacterial count of raw expressed breast milk must be with the acceptable range of expressed breast milk processing guideline [42]. In addition to total bacterial load, the types of bacteria which associated with infant mortality and morbidity also critical. Enterobacteriaceae and Staphylococcus aureus bacteria are bacteria associated with infant infection [40]. Additionally based on the guideline of HMBANA, in raw expressed breast milk, if the total bacterial count exceeds $5 \log 10 \mathrm{CFU} / \mathrm{ml}$, and $4 \log 10 \mathrm{CFU} / \mathrm{ml}$ for both Entrobactericeae and Staphylococcus aureus the expressed donor breast milk could not be used for feeding new born baby. In pasteurized expressed donor breast milk, no detectable bacterial count is allowed.

In our present study, In raw breast milk sample, total aerobic bacteria, Enterobacteriaceae, and Staphylococcus aureus were detected in the range of $4.51 \log 10 \mathrm{CFU} / \mathrm{ml}$ to $4.88 \log 10 \mathrm{CFU} / \mathrm{ml}, 3.02 \log 10 \mathrm{CFU} / \mathrm{ml}$ to $3.48 \log 10 \mathrm{CFU} /$ $\mathrm{ml} 3.34 \log 10 \mathrm{CFU} / \mathrm{ml}$ to $3.56 \log 10 \mathrm{CFU} / \mathrm{ml}$ respectively. These bacterial load or growth of two month storage time was within the acceptable range of the guideline of HMBANA [42]. However, in the entire pasteurized breast milk sample, no bacteria were detected in two month cold storage time. Similarly, study in South Africa about the bacterial safety of donor human milk from milk banking, the finding showed that there was no evidence of bacterial contamination and no adverse event from feeding was detected [47]. Supporting evidence was study conducted in Japan on the bacteriological safety of human milk storage in deep freezes over a period of four weeks. Result showed no increase in bacterial count of fresh sample. From our result we concluded that our result is safe from bacterial contamination and in line with the guideline [42].

Sensory quality is indispensible when considering provision of stored breast milk. Expressed breast milk could be expired or bring unpleasant sensory attribute over storage time associated to microbiological decomposition of components, activity of inherent enzymes or chemical interaction among nutrient. In our study raw breast milk sample developed off flavor over two month of storage. But in pasteurized breast milk sample no off flavor was produced in two month of cold storage time. This finding also supported in study conducted in Brazil in the study of relationship between off-flavor and microorganism load which showed the consistence relation between of flavor and microbial load. Pasteurization eliminates most microorganisms which decompose the nutrient. In addition it also denature intrinsic enzymes hence minimize decomposition. Moreover, cold storage temperature also slows down the rate of chemical reaction. So pasteurization and cold storage contribute for maintaining the sensory quality of pasteurized donor human milk [40].

\section{Conclusion}

Breast milk provides the optimal nutrition for growing infants. This is because it contains all the nutrients a baby needs in exactly the right proportions, which are easily digestible and well tolerable by infant immature gut. It also contains biologically active live cells which promote health and helps to develop a passive acquired immunity 
by transferring antibodies developed by the mother. In recognition of the vital role that breast milk plays in boosting infant's growth, development and overall health; the World Health Organization (WHO) recommends exclusive breastfeeding for the first six months of a child's life.

Globally, the coverage of exclusive breastfeeding is below half. Similarly, in Ethiopia, the coverage of exclusive breastfeeding rate is about $52 \%$, which is sub optimal and far from widely accepted-universal coverage $\|$ target of $90 \%$ set by WHO. On the other hand neonatal mortality rate in developing countries is high which is 40 deaths per 1000 live birth. In Ethiopia also neonatal mortality rate is high, which is 37 deaths per 1000 live birth. Inadequate exclusive breastfeeding has a great share on neonatal especially, early neonatal death. Exclusive breastfeeding alone reduces the neonatal death, specially the death that occurs soon after birth (early neonatal death) by $13 \%$.

But there are a large group of infants such as; pre-term, low birth weight and ill infants who are unable to breastfeed because these new born babies are weak unable to suckle their mothers breast milk. Additionally, mother of preterm infants, at the time of birth may have difficulties in lactation to start. On such condition, WHO recommends pasteurized donor human milk as the next best feeding option for new born babies.

A human milk bank (HMB) is a specialized service established to recruit breast milk donors, collect donated milk, and then process, screen, store, and distribute the milk to meet infants' specific needs for optimal health. The aim of Human Milk Bank is to promote protect and support breastfeeding by providing safe, high-quality donor milk to fill a gap for those who need mother's milk but cannot receive it.

In our study majority of mothers and substantial number of health professionals never heard about the existence of Pasteurized Donor Human Milk bank. Majority of mothers did not need to feed their new born baby donor human milk mainly because of fear of transfer of disease or safety concern. This is due to lack of knowledge about its safety and nutritional quality both by mothers and health professionals. Few study participants also stated that their culture or religion prohibit them. Majority of health professionals express their worries the uncontrolled promotion and marketing of infant formula which undermine the value exclusive breastfeeding and donor human milk.

Majority of health professionals mentioned current trends such as; better awareness benefit of exclusive breastfeeding by mothers, the increasing number of mother who attends antenatal delivery and postnatal care at health facilities, government promotion of exclusive breastfeeding considered as opportunity we have if pasteurized donor human milk banking. On the other hand, lack of knowledge on its benefit and safety and hence attitude of mothers and health professionals about PDHMB, lack of enough facilities and infrastructure, uncontrolled promotion of infant formula and the strangeness of the program are among the challenges mentioned by study participants.

In our microbiological test pasteurization and deep freeze $\left(-20^{\circ} \mathrm{C}\right)$ can eliminate potential pathogenic bacteria and no bacteria was detected within two month storage. Additionally our sensory analysis showed that, pasteurized sample had no significant flavor change from fresh expressed breast milk over two month's storage time.

\section{Recommendation}

In general as any developing country Ethiopia has high premature and low birth weight birth. Still the breastfeeding rate is suboptimal which the major contributing factor for infant mortality rate is. Establishing pasteurized donor human milk banking will scale up the breastfeeding rate and reduce the infant mortality rate.

For public health program

$\checkmark$ SBCC works for the general community

$\checkmark$ Inclusion of higher officials, community figures and religious leaders in the SBCC

$\checkmark$ Public education about the benefit of donor human milk is crucial and training of health professionals

$\checkmark$ For governmental body and policy maker

$\checkmark$ How to incorporate donor human milk banking in to maternal and child health system For researchers

$\checkmark \quad$ Further more comprehensive and additional detail study and piloting of pasteurized donor human milk banking in selected hospitals

\section{Acknowledgment}

First and for most I would like to give my deepest appreciation to my advisors, Dr. Dawd Gashu and Dr. Adane Abera for their consistence support and relentless engagement to this work. Their direction, instruction and corrective action contribute to be lessoned and courage my future.

My appreciation and respect also goes to Dr. Abdulaziz Adish who encourage me in my choice the subject matter to be study.

Furthermore I would like to thank those pediatric ward staff nurse of Tkur Anbesa Specialized Teaching Hospital for their assistance in data collection specially breast milk sample collection and interviewing study mothers. 
Finally, I went to express my appreciation to Addis Ababa university Center for Food Science and Nutrition and Biology staff members for their indispensable support.

\section{References}

1. Heinig MJ, Dewey KG (1996) Health advantages of breast feeding for infants: a critical review. Nutrition research reviews 9(01): 89-110.

2. World Health Organization \& UNICEF (2003) Global strategy for infant and young child feeding. World Health Organization.

3. UNICEF \& World Health Organization (1989) Protecting, promoting and supporting breast- feeding: the special role of maternity services.

4. Ezeonodo A, Cen C, Cnicn M (2013) Expansion of the Baby-Friendly Hospital Initiative Ten Steps to Successful Breastfeeding into Neonatal Intensive Care: Expert Group Recommendations. Journal of Human Lactation 29(3): 300-309.

5. Perrine CG, Scanlon KS, Li R, Odom E (2012) BabyFriendly Hospital Practices and Meeting Exclusive Breastfeeding Intention. Pediatrics 130(1): 1-7.

6. Bertino E, Giuliani F, Occhi L, Coscia A, Tonetto P, et al. (2009) Benefits of donor human milk for preterm infants: current evidence. Early human development 85(10): S9-S10.

7. Boyd CA, Quigley MA, Brocklehurst P (2007) Donor breast milk versus infant formula for preterm infants: systematic review and meta-analysis. Archives of Disease in Childhood-Fetal and Neonatal Edition 92(3): F169-F175.

8. Arslanoglu S, Corpeleijn W, Moro G, Braegger C, Campoy C, et al. (2013) Donor human milk for preterm infants: current evidence and research directions. Journal of pediatric gastroenterology and nutrition 57(4): 535542.

9. Meinzen-Derr J, Poindexter B, Wrage L, Morrow AL, Stoll B, et al. (2009) Role of human milk in extremely low birth weight infants' risk of necrotizing enterocolitis or death. Journal of Perinatology 29(1): 57-62.

10. Arnold LD (2006) Global health policies that support the use of banked donor human milk: a human rights issue. Int Breastfeed J 1(26): 1-8.

11. Wight NE (2001) Donor human milk for preterm infants. Journal of perinatology: official journal of the California
Perinatal Association 21(4): 249-254.

12. Seid AM, Yesuf ME, Koye DN (2013) Prevalence of Exclusive Breastfeeding Practices and associated factors among mothers in Bahir Dar city, Northwest Ethiopia: a community based cross-sectional study. International breastfeeding journal.

13. Lander $T$ (2006) Neonatal and perinatal mortality: country, regional and global estimates. World Health Organization.

14. Kwast BE, Rochat RW, Kidane-Mariam W (1986) Maternal mortality in Addis Ababa, Ethiopia. Studies in family planning 17 (6 Pt 1): 288-301.

15. Black RE, Victora CG, Walker SP, Bhutta ZA, Christian P, et al. (2013) Maternal and child undernutrition and overweight in low-income and middle-income countries. The Lancet 382(9890): 427-451.

16. Black RE, Allen LH, Bhutta ZA, Caulfield LE, De Onis M, et al. (2008) Maternal and child undernutrition: global and regional exposures and health consequences. The lancet 371(9608): 243-260.

17. Bhutta ZA, Black RE (2013) Global maternal, newborn, and child health-so near and yet so far. New England Journal of Medicine 369(23): 2226-2235.

18. Almond D, Chay KY, Lee DS (2005) Effects of Low Birth Weight on the community. Quarterly Journal of Economics, pp: 1031-1083.

19. Lawn JE, Cousens S, Zupan J (2005) 4 million neonatal deaths: when? Where? Why? The Lancet 365(9462): 891900 .

20. Gebremariam A (2005) Factors predisposing to low birth weight in Jimma Hospital south western Ethiopia. East African medical journal 82(11): 554.

21. Tema T (2006) Prevalence and determinants of low birth weight in Jimma Zone, Southwest Ethiopia. East African Medical Journal 83(7): 366.

22. Blanc AK, Wardlaw $\mathrm{T}$ (2005) Monitoring low birth weight: an evaluation of international estimates and an updated estimation procedure. Bulletin of the World Health Organization 83(3): 178-185.

23. Blencowe H, Cousens S, Chou D, Oestergaard M, Say L, et al. (2013) Born too soon: the global epidemiology of 15 million preterm births. Reprod Health 10(Suppl 1): S2.

24. Beck S, Wojdyla D, Say L, Betran AP, Merialdi M, et al. (2010) The worldwide incidence of preterm birth: a 
systematic review of maternal mortality and morbidity. Bulletin of the World Health Organization 88(1): 31-38.

25. Black RE, Allen LH, Bhutta Z A, Caulfield LE, De Onis M, et al. (2008) Maternal and child under nutrition: global and regional exposures and health consequences. The lancet 371(9608): 243-260.

26. Chung M, Raman G, Trikalinos TA, Lau J (2009) A summary of the Agency for Healthcare Research and Quality's evidence report on breastfeeding in developed countries. Breastfeeding medicine 4(S1): S-17.

27. Duijts L, Jaddoe VW, Hofman A, Moll HA (2010) Prolonged and exclusive breastfeeding reduces the risk of infectious diseases in infancy. Pediatrics 126(1): e18-e25.

28. Owen CG, Martin RM, Whincup PH, Smith GD, Cook DG (2005) Effect of infant feeding on the risk of obesity across the life course: a quantitative review of published evidence. Pediatrics 115(5): 1367-1377.

29. Bener A, Hoffmann GF, Afify Z, Rasul K, Tewfik I (2008) Does prolonged breastfeeding reduce the risk for childhood leukemia and lymphomas?. Minerva pediatrica 60(2): 155-161.

30. Hintz SR, Kendrick DE, Stoll BJ, Vohr BR, Fanaroff AA, et al. (2005) Neurodevelopmental and growth outcomes of extremely low birth weight infants after necrotizing enterocolitis. Pediatrics 115(3): 696-703.

31. Shah DK, Doyle LW, Anderson PJ, Bear M, Daley AJ, et al. (2008) Adverse neurodevelopment in preterm infants with postnatal sepsis or necrotizing enterocolitis is mediated by white matter abnormalities on magnetic resonance imaging at term. The Journal of pediatrics 153(2): 170-175.

32. Krause KM, Lovelady CA, Peterson Bl, Chowdhury N, Østbye $\mathrm{T}$ (2010) Effect of breast-feeding on weight retention at 3 and 6 months postpartum: data from the North Carolina WIC Programme. Public health nutrition 13(12): 2019-2026.

33. Schwarz EB, Ray RM, Stuebe AM, Allison MA, Ness RB, et al. (2009) Duration of lactation and risk factors for maternal cardiovascular disease. Obstetrics and gynecology 113(5): 974.

34. Barclay AR, Russell RK, Wilson ML, Gilmour WH, Satsangi J, et al. (2009) Systematic review: the role of breastfeeding in the development of pediatric inflammatory bowel disease. The Journal of pediatrics 155(3): 421-426.

35. Stuebe AM, Willett WC, Xue F, Michels KB (2009) Lactation and incidence of premenopausal breast cancer: a longitudinal study. Archives of internal medicine 169(15): 1364-1371.

36. Da Silveira MMM, da Silva Maia PR, Ferreira SLC, de Almeida, JAG (2013) Gestão da Informação no Processo de Transferência Tecnológica: Estudo de caso na Rede Brasileira de Bancos de Leite Humano. Biblioteca Digital de la Asociación Latino- Iberoamericana de Gestión Tecnológica 1(1).

37. Protocol ABM (2010) ABM clinical protocol\# 8: human milk storage information for home use for full-term infants (original protocol March 2004; revision\# 1 March 2010). Breastfeeding medicine 5(3): 127-130.

38. World Health Organization (1981) International code of marketing of breast-milk substitutes.

39. Bharadva K, Tiwari S, Mishra S, Mukhopadhyay K, Yadav B, et al. (2014) Human milk banking guidelines. Indian pediatrics 51(6): 469-474.

40. Chantry CJ, Howard CR (2013) Clinical protocols for management of breastfeeding. Pediatric Clinics of North America 60(1): 75-113.

41. Asquith MT (1989) Human Milk Banking Association of North America.Journal of perinatology: official journal of the California Perinatal Association 9(1): 121.

42. Huertas KP (2015) A Sunrise Review: Mandated Healthcare Coverage for Banked Human Milk.

43. Afif EK, Unger S (2012) The concept of milk kinship in Islam issues raised when offering preterm infants of Muslim families donor human milk. Journal of Human Lactation 28(2): 125-127.

44. Ghaly M (2012) Milk banks through the lens of Muslim scholars: One text in two contexts. Bioethics 26(3): 117127.

45. Parker MG, Barrero-Castillero A, Corwin BK, Kavanagh PL, Belfort MB, Wang CJ (2013) Pasteurized human donor milk use among US level 3 neonatal intensive care units. Journal of Human Lactation 29(3): 381-389.

46. Coutsoudis I, Adhikari M, Nair N, Coutsoudis A (2011) Feasibility and safety of setting up a donor breastmilk bank in a neonatal prem unit in a resource limited setting: An observational, longitudinal cohort study. BMC public health 11(1): 356.

47. Coutsoudis I, Petrites A, Coutsoudis A (2011) Acceptability of donated breast milk in a resource limited South African setting. Int Breastfeed J 6(3). Centre for Clinical Practice at NICE (2010) Donor breast 


\section{Food Science \& Nutrition Technology}

milk banks: The operation of donor milk bank services.

48. Centre for Clinical Practice at NICE (2010) Donor breast milk banks: The operation of donor milk bank services.

49. Marks LR. Clementi EA, Hakansson AP (2012) The human milk protein-lipid complex HAMLET sensitizes bacterial pathogens to traditional antimicrobial agents. PloS one 7(8): e43514-e43514.

50. Fouda GG, Jaeger FH, Amos JD, Ho C, Kunz EL, et al. (2013) Tenascin-C is an innate broad-spectrum, HIV-1neutralizing protein in breast milk. Proceedings of the National Academy of Sciences 110(45): 18220-18225.

51. Koletzko B, Agostoni C, Bergmann R, Ritzenthaler K, Shamir R (2011) Physiological aspects of human milk lipids and implications for infant feeding: a workshop report. Acta Paediatrica 100(11): 1405-1415.

52. Eteng MU, Ebong PE, Eyong EU, Ettarh RR (2001) Storage beyond three hours at ambient temperature alters the biochemical and nutritional qualities of breast milk. African journal of reproductive health 5(2): 130-134.

53. García-Lara NR, Vieco DE, De la Cruz-Bértolo J, LoraPablos D, Velasco NU, et al. (2013) Effect of Holder pasteurization and frozen storage on macronutrients and energy content of breast milk. Journal of pediatric gastroenterology and nutrition 57(3): 377-382.

54. Buss IH, McGill F, Darlow BA, Winterbourn CC (2001) Vitamin $C$ is reduced in human milk after storage. Acta Paediatrica 90(7): 813-815.

55. Friend BA, Shahani KM, Long CA, Vaughn LA (1983) The Effect of Processing and Storage on Key Enzymes, B Vitamins, and Lipids of Mature Human Milk I; Evaluation of Fresh Samples and Effects of Freezing and Frozen Storage. Pediatric research 17(1): 61-64.

56. Addy PAK, Antepim G, Frimpong EH (2004) Prevalence of pathogenic Escherichia coli and parasites in infants with diarrhoea in Kumasi, Ghana. East African medical journal 81(7): 353-357.

57. Marín ML, Arroyo R, Jiménez E, Gómez A, Fernández L, Rodríguez JM (2009) Cold storage of human milk: effect on its bacterial composition. Journal of pediatric gastroenterology and nutrition 49(3): 343-348.

58. Yasuko H, Hiroko N, Yasuko I, Akihiro O, Seiji I, et al. (2013) Bacteriological Safety of Human Milk Storage (Original).

59. Mackenzie C, Javanparast S, Newman L (2013) Mothers' Knowledge of and Attitudes toward Human Milk Banking in South Australia A Qualitative Study. Journal of Human Lactation.

60. Parker MG, Barrero-Castillero A, Corwin BK, Kavanagh PL, Belfort MB, et al. (2013) Pasteurized human donor milk use among US level 3 neonatal intensive care units. Journal of Human Lactation 29(3): 381-389.

61. Vieira AA, Soares FVM, Pimenta HP, Abranches AD, Moreira MEL (2011) Analysis of the influence of pasteurization, freezing/thawing, and offer processes on human milk's macronutrient concentrations. Early human development 87(8): 577-580.

62. Kaiser A (1993) A New Multi-Category Classification of Subcutaneous Fat Deposits of Songbirds (Una Nueva Clasificación, con Multi-categorías, para los Depósitos de Grasa en Aves Canoras). Journal of Field Ornithology 64(2): 246-255.

63. Naicker M, Coutsoudis A, Israel-Ballard K, Chaudhri R, Perin N, et al. (2015) Demonstrating the Efficacy of the FoneAstra Pasteurization Monitor for Human Milk Pasteurization in Resource-Limited Settings. Breastfeeding Medicine 10(2): 107-112.

64. Romeu-Nadal M, Chavez-Servin JL, Castellote AI, Rivero M, Lopez-Sabater MC (2007) Oxidation stability of the lipid fraction in milk powder formulas. Food chemistry 100(2): 756-763.

65. Balasubramaniam VM, Ting EY, Stewart CM, Robbins JA (2004) Recommended laboratory practices for conducting high-pressure microbial inactivation experiments. Innovative Food Science \& Emerging Technologies 5(3): 299-306.

66. Mehari GM, Valuist A, Hofvander Y, Upsal L, Vahlquist B (1976) Breast Milk composition in Ethiopian and Swedish mothers. The America J Clin Nutr 29: 441-451.

67. Kim JH, Chan CS, Vaucher YE, Stellwagen LM (2013) Challenges in the practice of human milk nutrition in the neonatal intensive care unit. Early human development 89: S35-S38.

68. Labbok MH, Wardlaw T, Blanc A, Clark D, Terreri N (2006) Trends in exclusive breastfeeding: findings from the 1990s. Journal of Human Lactation 22(3): 272-276.

69. Chung M, Raman G, Chew P, Magula N, Trikalinos T, et al. (2007) Breastfeeding and maternal and infant health outcomes in developed countries. Evid Technol Asses 153: $1-186$.

70. Fiscella K (1996) Racial disparities in preterm births. The role of urogenital infections. Public Health Reports 
111(2): 104 .

71. Greer FR, Sicherer SH, Burks AW (2008) Effects of early nutritional interventions on the development of atopic disease in infants and children: the role of maternal dietary restriction, breastfeeding, timing of introduction of complementary foods, and hydrolyzed formulas. Pediatrics 121(1): 183-191.

72. Lucas A (2005) Long-term programming effects of early nutrition-implications for the preterm infant. Journal of Perinatology 25: S2-S6.

73. Singhal A, Cole TJ, Lucas A (2001) Early nutrition in preterm infants and later blood pressure: two cohorts after randomised trials. The Lancet 357 (9254): 413-419.

74. Abhulimhen-Iyoha BI, Okonkwo IR, Ideh RC, Okolo AA (2015) Mothers' perception of the use of banked human milk for feeding of the infants. Nigerian Journal of Paediatrics 42(3): 223-227.

75. Lam EY, Kecskés Z, Abdel-Latif ME (2012) Breast milk banking: Current opinion and practice in Australian neonatal intensive care units. Journal of paediatrics and child health 48(9): 833-839.

76. Marín ML, Arroyo R., Jiménez E, Gómez A, Fernández
L, et al. (2009) Cold storage of human milk: effect on its bacterial composition. Journal of pediatric gastroenterology and nutrition 49(3): 343-348.

77. Yasuko H, Hiroko N, Yasuko I, Akihiro O, Seiji I, et al. (2013) Bacteriological Safety of Human Milk Storage (Original).

78. Keim SA, Hogan JS, McNamara KA, Gudimetla V, Dillon CE, et al. (2013) Microbial contamination of human milk purchased via the Internet. Pediatrics 132(5): e1227-e1235.

79. Novak FR, Junqueira AR, Dias MDS, Almeida JA (2008) Sensorial analysis of expressed human milk and its microbial load. Jornal de Pediatria 84(2): 181-184.

80. Ukegbu PO, Uwaegbute AC, Ijeh II, Ukegbu AU (2013) Bacterial Load in Expressed and Stored Breast Milk of Lactating Mothers in Abia State, Nigeria. African Journal of Food, Agriculture, Nutrition and Development 13(4): 8139-8154.

81. Ma T, Zuazaga G (1942) Micro-Kjeldahl determination of nitrogen. A new indicator and an improved rapid method. Industrial \& Engineering Chemistry Analytical Edition 14(3): 280-282. 